\title{
Influence of environmental factors on agrobiological indexes of a grape of cultivar Odeskyi Chornyi
}

\author{
V. Vlasov, \\ Corresponding Member of NAAS of Ukraine, \\ Doctor of Agricultural Sciences \\ H. Popova \\ Influence of environmental factors on agrobiological indexes of a grape of cultivar Odeskyi
} Chornyi

The purpose. To study correlation between ecological conditions, modern state and areas of grape plantations using databases of a cadastre of vineyards and results of field experiment. Methods. Topographical (for assessment of space elements of land forms), cartographical (at formulation ampeloecological maps for selection ampeloecotopes), calculated. At study of influence of environmental factors on agrobiological indexes of a grape they determined amount of racemations for a scrub (pieces), productivity for a scrub $(\mathrm{kg})$, percentage by weight of sugars and titrable acids in a grape $(\mathrm{g} / \mathrm{dcm} 3)$, average weight of a cluster of grapes (g). Results. Allocation is studied of areas of grape plantations on regions of Odessa oblast in the period of 1979-2015 by means of the manager of database of cadastre of vineyards Vin-Cad-Ukr. Conclusions. Results of probes confirm link between quality and amount of gained products with ecological conditions of terrain of growing of plantations and specify necessity of application of ecological investigations at solution of questions of their allocation.

Key words: cadastre of vineyards, database, Vin-Cad-Ukr, ampeloecotope, ampelo-ecological probes, Odeskyi Chornyi, agrobiological indexes.

Relevance and experience of research in the world. The problem of reducing the area under vineyards in the Odessa region is associated with a large number of different factors, one of which is the lack of an environmentally sound choice of the area for the laying of grape plantations. In recent decades scientists NSC "Tairov Institute of viticulture and winemaking" conducted large-scale studies of conditions of growth and fruiting of grapes, in which the most complete disclosure of genetic abilities of the forcibly-clavicle combinations is possible. It is proved that the selection of territories with optimal ecological conditions at the varietal level is possible under a complex system approach to the study of quantitative indicators of the main environmental factors: relief, microclimate and soil in relation to the culture of grapes. On the territory of Moldova, comprehensive studies of the impact of environmental factors on the cultivation of grapes were conducted under the guidance of Ya.M. Godelman, M.P. Rapci, M.F. Kisil. Since the 70's issues of the ecology of wine-growing regions in order to optimize the use of land resources and the production of quality winemaking products in the Russian Federation are engaged scientists of the All-Russian Research Institute of Viticulture and Winemaking Ya.I. Potapenko under the leadership of M.R. Tolokov [1].

Problem statement: According to statistics, in recent years there has been a tendency to reduce areas under vineyards, most of which are overgrown young plantings. The problem is caused by underestimation of the environmental conditions of the territory on the vineyards, the quality and quantity of the products received, and, accordingly, the profit that can be obtained. The aims and objectives of the research are directed at determining the link between the reduction of vineyard areas and the use of environmental justification for placement of planting sites.

The purpose of the research is to study the relationship between environmental conditions and the present state and area of plantings, using vineyard cadastre database and results of field experiment.

Materials and methods of research. The data for the vineyard cadastre of 2012 and 2015 and the ampelecological characteristics of the studied territory were systematized in the Vin-Cad-Ukr software product and analyzed using the MS Exel table editor. When selecting a site for conducting research, the following methods were used: topographic (for the estimation of spatial elements of relief), cartographic (when compiling ampeloecological maps for the allocation of ampelocotopes) and the calculation method. In studying the influence of environmental factors on agrobiological indicators of grapes were determined: the number of bunches per bush, yield per bush $(\mathrm{kg})$, mass concentration of sugars and titrated acids in grapes (g/dm3), average weight of grape bunches $(\mathrm{g})$ [2].

Research results. In 2012-2015, the Institute carried out a large-scale work on the inventory of vineyards in the Odessa region. As a result of the research, a database is created that gives increased opportunities in 
obtaining data on vineyards of a particular region, or farm, as the area, varietal composition, yield, liveliness, environmental conditions and coordinates of the site location [3-6].

The data from the 1979, 2010, 2012, and 2015 cadastres confirm the tendency to reduce the area under vineyards, while research has shown that one of the reasons is the upsetting of young plantings laid down in the last 10-15 years, which have suffered significant frost damage $[7,8]$.

Thus, in 1979, vineyards of 18 districts of the Odessa region amounted to 78141.0 hectares. The main arrays of plantations were concentrated in Artsyzsk, Bilhorod-Dnistrovsky, Bolgrad, Izmail, Ovidiopol, Saratsky, Tarutinsky, and Tatarbunary districts (the area of each of these areas was more than 5,000 hectares) (Fig. 1).
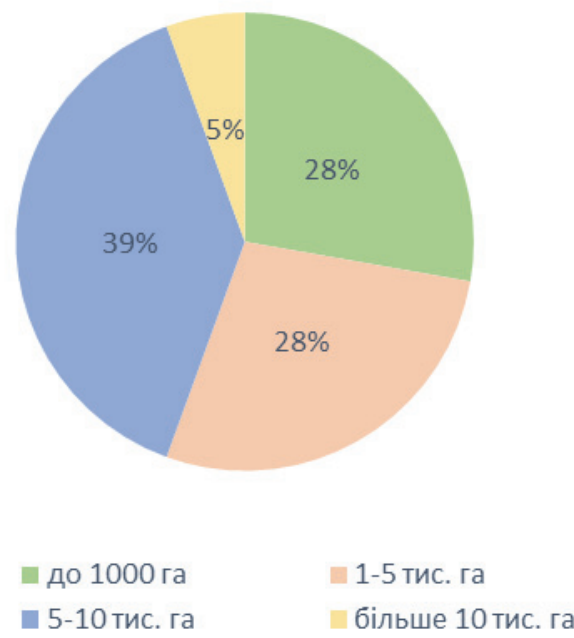

a)

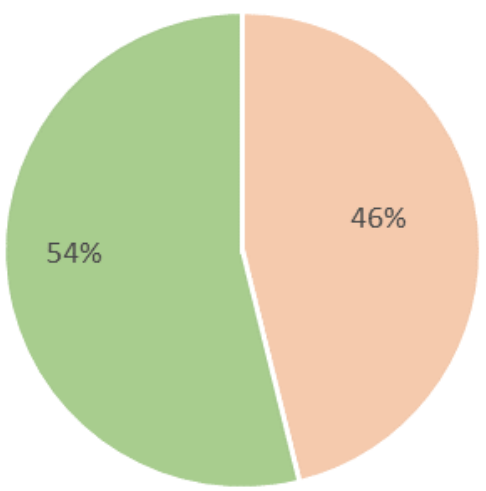

по 1000 га = 1-5 тис. га

b)

Fig. 1. Structure of wine-growing farms in the areas of grape plantations in the Odessa region (a - 1979, b - 2015)

In 2015, the total area of grape plantations was 19632,6 hectares, which is $75 \%$ less than the area of 1979, in 6 out of 18 regions ( $30 \%$ of the total) vineyards were completely overgrown (Fig. 2) [6].

It should be noted that the area of plantings within the same area does not exceed 4.5 thousand hectares, while in 1979, the largest massifs of vineyards in one area were more than 10 thousand hectares.

One of the possible reasons for the current situation is the lack of scientific justification for selecting sites, the non-conformity of the requirements of varieties to the ecological conditions of the territories [9].

The research of ampoleecologists (V.G. Unguryan, Ya.M. Godelman, M.F. Kisil) is aimed at solving the problem of inefficient use of ecological resources of the territories and relying on complex multi-year studies, which need to be clarified for use in specific areas of the Odessa region and economic Analysis that is more understandable for representatives of agribusiness $[1,10]$.

In scientifically grounded selection of sites under the tab attention is paid to the analysis of the spatial distribution of environmental conditions, which includes the characteristics of the elements of relief, soil cover and climate, which have a significant impact on the conditions of growth, development and formation of grape varieties of various varieties. [11] It has been proved that the vineyards are optimal for slopes of warm exposures - southern, southwestern, and western, and the slopes of northern exposures are unsuitable for vineyards because they are not frost-free. It is equally important to establish the optimal speed and exposure of the slopes, depending on which different microclimatic and micronutrient conditions are created in one and the same locality. In assessing the territory for the laying of vineyards, it is important to take into account the shape of the relief (slopes, divides, valleys, etc.). [12] Closed basins that are unsuitable for growing grapes, where there are usually long lunch and early autumn frostbite, and where, in the summer, vineyards suffer from illness and damage due to poor ventilation pests. Despite the high plasticity of grapes, heavy soils (clayey, heavy-grained), characterized by weak permeability and unfavorable thermal properties, are not recommended for laying vineyards, and light soils (sandy loam, loamy loam and loamy) with favorable waterphysical properties are optimal for vineyards [9]. Climatic conditions relate to the main factors influencing the growth, development and fruiting of grapes. The average of absolute air temperature minima, as the main indicator of hibernation, for the area under study in the winter is $-14,6 \ldots-17,6^{\circ} \mathrm{C}$, and $1-2$ times in 10 years it decreases to $-20 \ldots-25^{\circ} \mathrm{C}$, that is, in 2015 , the minimum temperatures have fallen to critical values for grapes [13].

The object of the study was 2 plots on the farm of SE "SF O.V. Suvorov" of the Bolgrad region (Ampeloecotop 1 and Ampeloecotop 2) of the Odessky Chorny variety with the same varieties of rootstocks, agrotechnical conditions of processing and various topographical, soil and climatic conditions (Fig. 2). 


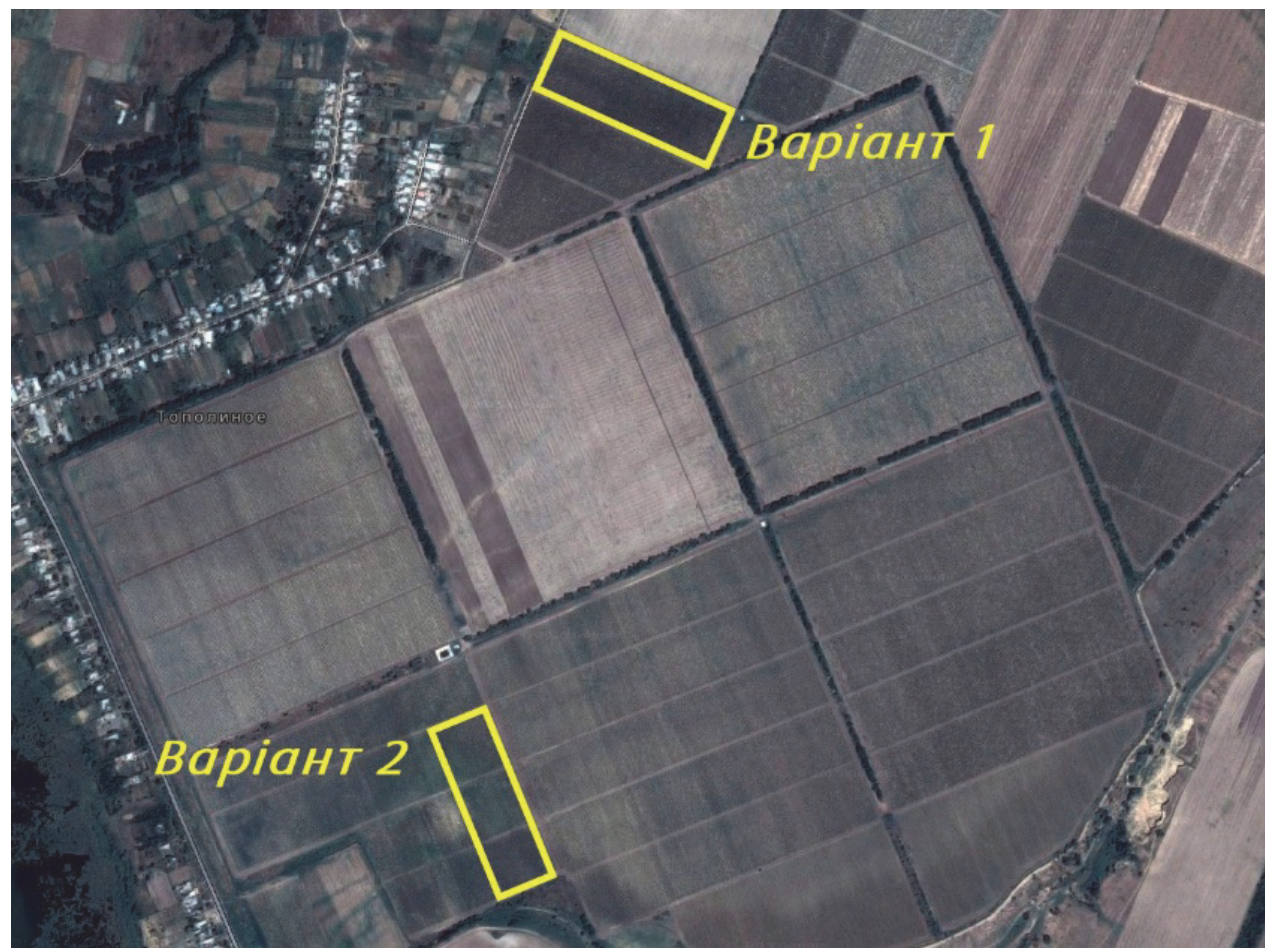

Fig. 2. General view of the study area (satellite imagery)

These ampeloecotopes are within the limits of one ampeloecological area - the Southern spurs of the Tigets Hills. However, Ampelocentrum 1 is located in the middle part of the slope of the western exposition, the soil profile is weakly blurred, and Ampelocentrum 2 is located within the river valley with a mediumchange soil profile (Table 1). The ecological conditions of plots in favorable weather conditions provide almost identical indices of yield and quality of products.

Table 1. Comparative characteristics of ecological conditions of the territory and agrotechnics on the sites of Ampeloecotop 1 and Ampeloecotop 2

\begin{tabular}{|c|c|c|c|}
\hline № & Investigated indicators & Ampeloecotop 1 & Ampeloecotop 2 \\
\hline \multicolumn{4}{|c|}{ Ampeloecological conditions } \\
\hline 1 & $\begin{array}{c}\text { Exposure and } \\
\text { precipitancy of the } \\
\text { slopes }\end{array}$ & Ws., до $3^{\circ}$ & S/Ws, до $3^{\circ}$ \\
\hline 2 & $\begin{array}{l}\text { Microclimate area } \\
\text { (Mean value of the } \\
\text { absolute minimum air } \\
\text { temperature) }\end{array}$ & $-20,0-22,5^{\circ} \mathrm{C}$ & $-22,5-25,0^{\circ} \mathrm{C}$ \\
\hline 3 & $\begin{array}{l}\text { Amount of active } \\
\text { temperatures }\end{array}$ & $3301-3400{ }^{\circ} \mathrm{C}$ & \\
\hline 4 & $\begin{array}{c}\text { Soil cover, cipher of the } \\
\text { agro group }\end{array}$ & $\begin{array}{l}\text { chernozems common low } \\
\text { molecular weight }(65 \mathrm{~g})\end{array}$ & $\begin{array}{l}\text { chernozems common middle-gravel, } \\
\text { medium-grained }(66 \mathrm{~g})\end{array}$ \\
\hline 5 & $\begin{array}{l}\text { The content of active } \\
\text { carbonates }\end{array}$ & $4,1-10,0 \%$ & \\
\hline 6 & Humus reserves & $201-300 \mathrm{t} / \mathrm{ha}$ & $101-200 \mathrm{t} / \mathrm{ha}$ \\
\hline \multicolumn{4}{|c|}{ Agricultural characteristics } \\
\hline 1 & Grape variety & \multicolumn{2}{|c|}{ Odessky Chorny } \\
\hline 2 & Rootstock & \multicolumn{2}{|c|}{ Ripariya x Rupestris 101-14 } \\
\hline 3 & Year of landing & \multicolumn{2}{|c|}{2003} \\
\hline 4 & Landing scheme & \multicolumn{2}{|c|}{$3,0 \times 1,5 \mathrm{~m}}$. \\
\hline 5 & Shrub formation & \multicolumn{2}{|c|}{ One-fence border with a height of a shtamb of $100 \mathrm{~cm}$. } \\
\hline 6 & Lidiness of plantations & \multicolumn{2}{|c|}{$5 \%$} \\
\hline
\end{tabular}


As a result of the research, a comparative estimation of agrobiological indicators of the obtained grapes was carried out (including indicators of product quality).

Studies have shown that at the Ampeloecotope site 1, the estimated yield of grapes and the sugar content of wort is higher than the similar indices of ampeloecotope 2 (by $9.9 \%$ and $22.6 \%$ ), and the acidity of the wort is lower (by $11.5 \%$ ). Proceeding from this it can be concluded that the site under the vineyards of Ampeloecotop 1, given the ecological conditions, is located more correctly than the planting of the Ampeloecotope 2 (Table 2).

Table 2. Results of research on the influence of environmental factors on agrobiological indicators of grapes Odessky Chorny in 2014

\begin{tabular}{|c|c|c|c|c|c|}
\hline Options & $\begin{array}{c}\text { Number of } \\
\text { bunches } \\
\text { on the bush }\end{array}$ & $\begin{array}{c}\text { Average } \\
\text { weight of } \\
\text { bunch, } \mathrm{g}\end{array}$ & $\begin{array}{c}\text { Harvest on a } \\
\text { bush, } \\
\mathrm{kg}\end{array}$ & $\begin{array}{c}\text { Sugariness } \\
\mathrm{g} / \mathrm{dm}\end{array}$ & $\begin{array}{c}\text { Acidity, } \\
\mathrm{g} / \mathrm{dm}\end{array}$ \\
\hline Ampeloecotop 1 & 53 & 148,0 & 7,7 & 226 & 4,6 \\
\hline Ampeloecotop 2 & 51 & 137,2 & 7,0 & 175 & 5,2 \\
\hline
\end{tabular}

Weather conditions for 2014-2015 were unfavorable for a grapevine [14]. Damage to frost (January 8 , the temperature in the air was $-20,2^{\circ} \mathrm{C}$, the surface of the snow $-29,4^{\circ} \mathrm{C}$, January $9-20,2^{\circ} \mathrm{C}-27,8^{\circ}$ $\mathrm{C}$, respectively), led to a significant decline in yield crops Ampeloecotop 1 (on average by 53\%) - Table. 3 . The yield of Ampeloecotop 2 amounted to an average of $0.3 \mathrm{~kg} / \mathrm{bush}$, which indicates an actual lack of yield (96\% less compared to 2014) (Fig. 4).

Table 3. Results of research on the influence of environmental factors on agrobiological indicators of grapes the Odessky Chorny in 2015

\begin{tabular}{|l|c|c|c|c|c|c|c|}
\hline Options & $\begin{array}{c}\text { Load } \\
\text { on the bush } \\
\text { shoots }\end{array}$ & $\begin{array}{c}\text { Number of } \\
\text { bunches } \\
\text { on the } \\
\text { bush }\end{array}$ & $\begin{array}{c}\text { Average } \\
\text { weight of } \\
\text { bunch, g }\end{array}$ & $\begin{array}{c}\text { Harvest } \\
\text { on a } \\
\text { bush, } \\
\mathrm{kg}\end{array}$ & $\begin{array}{c}\text { Sugariness } \\
\mathrm{g} / \mathrm{dm}\end{array}$ & $\begin{array}{c}\text { Number } \\
\text { of } \\
\text { bunches } \\
\text { on the } \\
\text { bush }\end{array}$ & $\begin{array}{c}\text { Maturatio } \\
\mathrm{n} \\
\text { vines, \% }\end{array}$ \\
\hline $\begin{array}{l}\text { Ampeloecot } \\
\text { op 1 }\end{array}$ & 36 & 42 & 86,7 & 3,6 & 208 & 6,3 & 90 \\
\hline $\begin{array}{l}\text { Ampeloecot } \\
\text { op 2 }\end{array}$ & 26 & 5 & 62,5 & 0,3 & 226 & 6,3 & 90 \\
\hline
\end{tabular}

In fig. 3 it is evident that the number of clusters in the Ampeloecctopus bushes 1 in 2014 is only $3.8 \%$ more than the Ampelococcus index 2. By the same indicator in 2015 , the difference is $88.1 \%$.

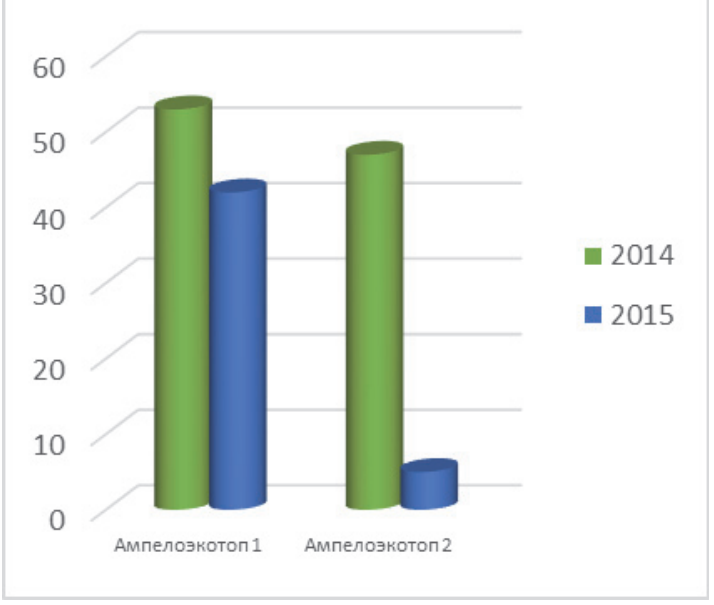

a)

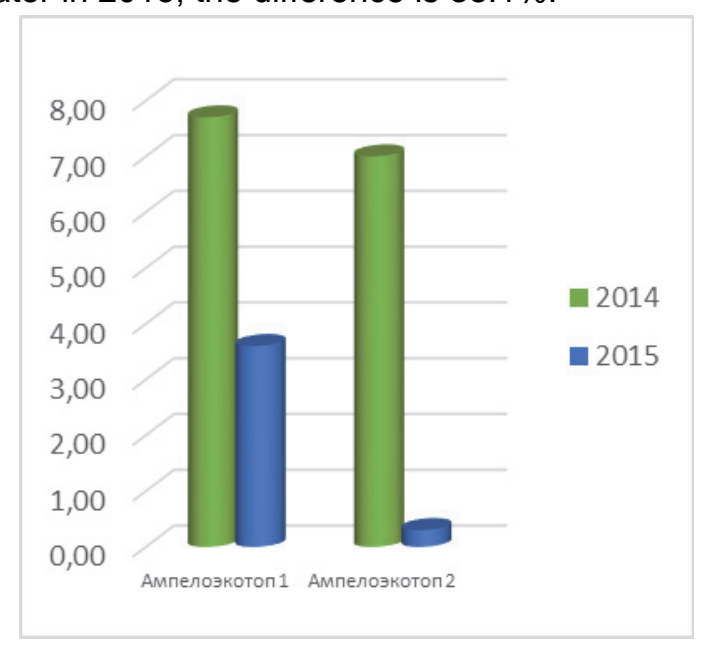

b)

Fig. 3. Number of bunches in the bush (a) and average yield from the bush (b) Ampelocetop 1 and Ampelocetop 2 (2014-2015).

In order to provide a more accurate picture of the patterns of plant behavior in a particular area, during the experiment, it was decided to pay attention not only to the analysis of agrobiological indicators, 
depending on the environmental conditions of the territory on which the experimental sites are located, but also on the economic efficiency of the production of grapes in selected areas [15]. The data obtained during the experiment confirm that the placement of the vineyard without the environmental justification of the choice of the territory entails heavy economic consequences.

According to the landing schemes $3 \times 1,5$, the lameness of plantations $5 \%$ and the average purchase cost of technical grapes in 2015 is 5,5 UAH, profit from 1 hectare of vineyard Ampeloecotop 1 to 8.5 thousand $\mathrm{UAH}$, above the corresponding indices of Ampeloecotope 2.

Given that in the large-scale enterprise the area of grape plantations can be 500 hectares or more, for the quick estimation of profitability indicators were given the estimated profit from 1 and 50 hectares (Table 4, 5).

Table 4. Indicators of economic efficiency of production at sites Ampeloecotop 1 and Ampeloecotop 2 in 2014 *

\begin{tabular}{|c|c|c|c|c|c|}
\hline & Yield, c / ha & $\begin{array}{c}\text { Profit, } \\
\text { UAH / ha }\end{array}$ & $\begin{array}{c}\text { Difference, } \\
\text { UAH }\end{array}$ & $\begin{array}{c}\text { Profit from 50 } \\
\text { hectares, UAH }\end{array}$ & $\begin{array}{c}\text { Difference, } \\
\text { UAH }\end{array}$ \\
\hline Ampeloecotop 1 & 162,6 & 89400,9 & \multirow{2}{*}{8505,1} & 4470043 & \multirow{2}{*}{425253,9} \\
\cline { 1 - 2 } & 147,1 & 80895,8 & & 4044789 & \\
\hline
\end{tabular}

* yield is obtained by the calculation method

Table 4 shows that in a year with favorable weather conditions for growing grapes (for the Bolgrad region - the sum of active temperatures not lower than $3513^{\circ} \mathrm{C}$, duration with $\mathrm{t}^{\circ} \mathrm{C}>10^{\circ}$ more than 187 days, annual rainfall is not less than $505 \mathrm{~mm}$, the minimum of temperature is not lower than the critical for the variety Odessky Chorny value $-25^{\circ} \mathrm{C}$ ) the large vineyards (an area of 500 hectares) in which $10 \%$ of the vineyards are placed without scientific justification may not receive $425000 \mathrm{UAH}$ [14].

In a year with unfavorable weather conditions, the loss will amount to about $38000 \mathrm{UAH}$ from 1 ha of the vineyard and about 2 million UAH from 50 hectares of vineyard, placed without an environmental justification (Table 5).

Table 5. Indicators of economic efficiency of production at sites Ampelocotope 1 and Ampelococcus 2 in 2015 *

\begin{tabular}{|c|c|c|c|c|c|}
\hline & Yield, c / ha & $\begin{array}{c}\text { Profit, } \\
\text { UAH / ha }\end{array}$ & $\begin{array}{c}\text { Difference, } \\
\text { UAH }\end{array}$ & $\begin{array}{c}\text { Profit from } \\
50 \text { hectares, } \\
\text { UAH }\end{array}$ & $\begin{array}{c}\text { Difference, } \\
\text { UAH }\end{array}$ \\
\cline { 1 - 2 } Ampeloecotop 1 & 76 & 41800,0 & \multirow{2}{*}{38335,0} & 2090000,0 & \multirow{2}{*}{1916750,0} \\
\cline { 1 - 3 } & 6,3 & 3465,0 & & 173250,0 & \\
\hline
\end{tabular}

* yield is obtained by the calculation method

The results obtained show the difference of the yield on sites with different ecological conditions and need to continue the research. The problem of placing grape plots without taking into account environmental conditions entails economic losses and one of the options for solving this problem is the unprofitability of such production is the development of projects for optimizing the location of grape plantations. This approach will promote the effective use of the ecological resources of the territories and reduce economic losses in production, which in turn will contribute to the development of the wine-growing sector as a whole.

\section{Conclusions}

The obtained results represent the connection of the quality and quantity of the products obtained with the ecological conditions in the area of plantations cultivation.

In 2015, due to unfavorable weather conditions, the yield of grapes on the Ampeloecotop 1 (the average part of the slope of the western exposition) decreased by 53\% and Ampeloecotop 2 (located within the river valley) - by $96 \%$ (compared with 2014). Losses in profit from 1 hectare of Ampeloecotop 1 vineyard amounted to 47.6 thousand UAH, and Ampeloecotop 2 - 77.4 thousand UAH in accordance.

The results confirm the need for ecologically sound selection of the territory for the laying of vineyards and the development of projects for the placement of grape plantations, taking into account the characteristics of the varieties and the applied agricultural equipment.

\section{Bibliography}

1. Kisil M.F. Problems and resources of ecologization of viticulture Moldova / M. F. Kisil // Omnibus. 2001. - No. 12. - P. 14-15. 
2. Dospekhov B.A. Field experiment (with basics of statistical processing of research results) / B. A. Dospekhov. - M .: Agropromizdat, 1985. - $351 \mathrm{p}$.

3. Geoinformation systems and databases: methodical instructions for practical classes / compilers: S.Yu.Markov, A.I.Kordas, N.P. Yavtushenko. - K.: KNUBA, 2001. - 90 p.

4. Data base of the vineyard cadastre informational system / C. Huţanu, Gh. Nistor, D. Pădure // University "1 Decembrie 1918" of Alba lulia GeoCAD. - 2012

5. Final report on research work "Establishing a vineyard cadastre of Ukraine taking into account environmental conditions" under the agreement with the Ministry of Agrarian Policy and Food of Ukraine No. 59. - National Scientific Center "Tairov Institute of Viticulture and Winemaking" - Odessa - 2012. - $175 \mathrm{p}$.

6. Final report on research work "Technical and economic and environmental justification of vineyard placement, monitoring of their condition, vineyard cadastre of the Odessa region" is the priority task of the Regional Program for the Development of the Agro-Industrial Complex of the Odesa Region for 2014-2018. National Scientific Center "Tairov Institute of Viticulture and Winemaking" - Odessa - 2015. - $120 \mathrm{p}$.

7. Grape Cadastre of the Ukrainian SSR / [executors. I. G. Mironenko and others]. -Simferopol, 1980. - 88 p.

8. Grape Cadastre of Ukraine / [developed. S. I. Miller et al.]. - K., 2010. - 97 p.

9. Vlasov V.V. Agri-ecological substantiation of the cadastre of vineyards of Ukraine

I V.V. Vlasov, G.V. Lyashenko, O. Yu. Vlasova, O. F. Shaposhnikova // Bulletin of Agrarian Science. 2012. - No. 2. - P. 60-62.

10. Unguryan V.G. Soils and grapes / V.G. Unguryan. - Chisinau: Shtiintsa, 1979. - 212 p.

11. Instructions for designing orchards, vineyards and nurseries. - $M$.: Agropromizdat, 1986. $-57 \mathrm{p}$.

12. Influence of climate, soil, and cultivar on terroir / Cornelis van Leeuwen, Philippe Friant, Xavier Chone and others. // Am. J. Enol. Vitic - 2004: 55: 3 (2004). - P. 207-217

13. Melnyk E. B. Agro-climatic assessment of the formation of productivity of grapes: author's abstract. dis ... Candidate s.-g. Sciences: 16.12.2010 / Ella Borisovna Melnyk. - Tairova, 2010. - 20 p.

14. Podgornaya S.V., Agroclimatic Justification of the Grape Culture Placement in the Odessa Region / S.V. Podgornaya, L.F. Ovchinnikova, V.I. Suzdalova // Viticulture and winemaking: rep. between those Sciences Sat - K.: Harvest, 1986. - Issue. 29. - P. 31-35.

15. Negrul'm A.M. Interrelation of grape harvest and its quality (results of the discussion) / A.M. Negrul // Winemaking and viticulture of the USSR. - 1961. - No. 1. - P. 22-26. 